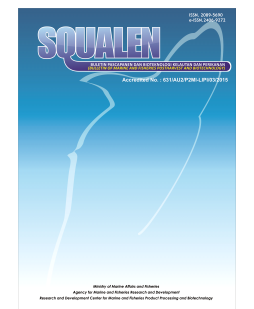

\title{
OPTIMUM AGE OF STARTER FOR MICROBIAL TRANSGLUTAMINASE (MTGase) PRODUCTION PRODUCED BY Streptomyces thioluteus TTA 02 SDS 14 AND CHARACTERIZATION OF CRUDE ENZYME
}

\author{
Dewi Seswita Zilda ${ }^{1 *}$, Yusro Nuri Fawzya ${ }^{1}$, Lia Siti Nur'amaliyah ${ }^{2}$, \\ Hana Nurullita Prestisia ${ }^{2}$, Nisa Rachmania Mubarik ${ }^{2}$ and Puspita Lisdiyanti ${ }^{3}$ \\ ${ }^{1}$ Research Center for Marine and Fisheries Product Processing and Biotechnology, \\ Jalan KS. Tubun Petamburan VI, Slipi, Central Jakarta 10260, Indonesia \\ ${ }^{2}$ Biotechnology Study Programed,Postgraduate Faculty, Bogor Agricultural University, \\ Jalan Raya Dramaga Kampus IPB, Bogor 16680, Indonesia \\ ${ }^{3}$ The Research Center for Biotechnology, Indonesian Institute of Sciences \\ Jalan Raya Jakarta, Bogor KM 46, Cibinong 16911, Bogor, Indonesia \\ Article history: \\ Received: 3 February 2017; Revised: 27 April 2017; Accepted: 31 April 2017
}

\begin{abstract}
The condition of starter plays important role in enzyme production. Optimum starter will lead to the optimum yield of enzyme production. The experiments which were aimed to obtain the optimum age for starter of Streptomyces thioluteus TTA 02 SDS 14 from solid as well as liquid medium had been carried out which would be used for transglutaminase production. Medium used for culture maintenance, starter optimization and enzyme production was described by Bahrim. The result showed that $S$. thioluteus TTA 02 SDS 14 was ready to be used as starter after being cultured on solid medium continued in liquid medium each for 6 days. The enzyme production in a bioreactor using optimized starter produced enzyme with the highest activity after being fermented for 2 days with 150 rpm agitation. The crude enzyme active optimally at $45-50^{\circ} \mathrm{C}, \mathrm{pH}$ of 6 and no effect of metal ion and inhibitor on enzyme activity.
\end{abstract}

Keywords: transglutaminase, starter age, Streptomyces thioluteus

\section{Introduction}

Proteins can be improved and/or developed with new functional properties by chemical, physical or enzymatic methods (Gaspar \& Góes-Favoni, 2015). One of the enzyme used for this aim is transglutaminase (TGase) or protein-glutamine $\gamma$ glutamyl-transferase (EC 2.3.2.13) which catalyzes the formation of isopeptide and leads to the crosslinking of protein via formation of $\varepsilon$-( $\gamma$-glutamyl) lysine linkages where water may replace primary amine as acyl acceptor and form glutamic acid (Motoki \& Seguro, 1998). Transglutaminases are found in various of organisms such as mammalian tissues (Yasueda et al., 1994) invertebrates (Griffin et al., 2002) and plant (Falcone et al., 1993). This enzymes are $\mathrm{Ca}^{2+}$ dependent. Different character was showed by transglutaminase produced by microorganisms (Microbial Transglutaminase, MTGase) which $\mathrm{Ca}^{2+}$ independent. The first microorganism reported as MTGase producer is from the genus of Streptoverticillium which was discovered by Ando et al. (1989). The availability to produce in large quantities, ease of separation, and lack of regulation by calcium and guanosine- 52 -triphosphate (GTP) has propelled MTGase to be the main cross-linking enzyme used in both the food industry and biotechnology. MTGase presently utilized for a huge number of applications to conjugate proteins and peptides to small molecules, polymers, surfaces, and DNA, as well as to other proteins.

In fisheries, TGase is currently used to improve the mechanical properties of fish product (surimi, fillets,

${ }^{*}$ Corresponding author.

E-mail: seswitazilda@gmail.com 
separate). Overall surimi products in the Southeast Asian region are estimated to be 315,800 metric tons in 2005 (Pangsorn et al., 2007). Surimi can be used to prepare a variety of processed foods such as kamaboko, kani (crab) kamaboko, chikuwa, satsumaage, fish sausages, fish balls, etc. High quality surimi yields flexible gel with white color. Although the quality of surimi products depends mainly on their gelling properties, but the product contained healthy and natural ingredient also possess added value for the consumer. The quality of fish mince or surimi and the type of ingredients used will affect the gel properties. Technological functions of the ingredients will determine textural properties. They also have antimicrobial and antioxidant and/or nutritional function.

Since TGase in the local market is still supplied by import due to unavailability of domestic industry, exploration and invention of new local transglutaminase producing microorganisms will create opportunities for domestic industry to produce transglutaminase using low price local raw material, which eventually will generate competitive transglutaminases to those currently supplied as imported products. The use of transglutaminase produced by domestic industry will reduce the production cost thus resulting products with affordable price.

For the first time, the study on transglutaminase producing microorganisms using local isolates have been carrying out. The screening of Streptomyces had been done and some isolates were found as good potential candidates for MTGase producer. One of them is Streptomyces thioluteus TTA 02 SDS 14 which showed the highest activity among other isolates. Optimization of production and screening for the fine medium had been carried out (Fawzya et al., 2016) but the activity of MTGase produced by S. thioluteus TTA 02 SDS 14 showed instability. It was allegedly caused by the starter which was not in optimum condition for MTGase production. This paper will report the experiments that had been done to find the proper age of starter both solid and liquid. The optimum starter then used for MTGase production and the crude MTGase was characterized. The aim of the experiments were to determine the starter age of $S$. thioluteus TTA 02 SDS 14 both in solid and liquid media and produce the transglutaminase for enzyme characterization.

\section{Methods}

\subsection{Microorganisms and Medium}

Streptomyces thioluteus TTA 02 SDS 14 used was Biotechnology research Center, LIPI Cibinong.
Medium used for culture maintenance, starter optimization and enzyme production was described by Bahrim et al., (2010) which contained 1.5\% peptone water, $0.1 \% \mathrm{MgSO}_{4} \cdot 7 \mathrm{H}_{2} \mathrm{O}, 0.2 \% \mathrm{KH}_{2} \mathrm{PO}_{4}$, $0.5 \% \mathrm{Na}_{2} \mathrm{HPO}_{4}, 2 \%$ soy bean flour, $2.0 \%$ potato starch and $1.5 \%$ glucose.

\subsection{Starter Age}

The culture was freshened from glycerol stock by inoculating onto solid medium and incubated for 7 days before reinoculating on the same medium for many times. The fresh culture was inoculated on a new solid medium and incubated for 9 days. Started at day 3 , each day the colony was collected using $8 \mathrm{~mm}$ (d) tube and inoculated into $50 \mathrm{~mL}$ flask with $15 \mathrm{~mL}$ liquid medium. The activity of MTGase was measured after 3 days incubation. The morphology of colony was investigated every day. The optimum starter in solid medium then used to determine the age of starter into liquid medium before being inoculated into production medium. The colonies from selected age were inoculated into $50 \mathrm{~mL}$ flask with $15 \mathrm{~mL}$ medium (16 flasks). The sample collection was carried out after 3 to 9 days incubation by inoculating $5 \mathrm{~mL}$ of culture into $150 \mathrm{~mL}$ flask with $50 \mathrm{~mL}$ medium and fermented for 3 days before being measured for enzyme activity.

\subsection{Agitation for Enzyme Production}

Enzyme production was carried out in $5 \mathrm{~L}$ bioreactor with $2 \mathrm{~L}$ working volume. The starter $(200$ $\mathrm{mL}$ ) was prepared from the previous experiment and inoculated into $1.8 \mathrm{~L}$ of production medium. The agitation was varied to 100,150 and $200 \mathrm{rpm}$. Enzyme activity was measured every day for 9 days incubation.

\subsection{Enzyme Characterization}

One liter crude MTGase was produced using an optimum starter in a bioreactor with optimum agitation. The optimum temperature was determined by measuring enzyme activity at several temperatures $\left(25,30,35,37,40,45,50,55,60,65\right.$ and $\left.70^{\circ} \mathrm{C}\right)$. Determination of optimum $\mathrm{pH}$ was carried out at a range of $0.2 \mathrm{M}$ citrate buffer ( $\mathrm{pH} 3-6)$, phosphate buffer (pH 6-8) and Tris-HCl buffer (pH 8-9). Thermal stability was determined by incubating aliquots of enzyme at 40,45 , and $50^{\circ} \mathrm{C}$ for up to 240 minutes. The activity of enzyme was measured every 15 minutes. The activity of enzyme was presented as relative activity (\%). Effect of metal ion was determined by measuring enzyme activity in the presence of $1 \mathrm{mM}$ of $\mathrm{Na}^{+}, \mathrm{K}^{+}$, $\mathrm{Li}^{+}, \mathrm{Cu}^{+}, \mathrm{Ca}^{2+}, \mathrm{Mg}^{2+}, \mathrm{Zn}^{2+}$, and $\mathrm{Fe}^{3+}$ in chloride solution as well of chemicals and inhibitors ( $1 \mathrm{mM}$ and $5 \mathrm{mM}$ ) 
of ethylenediamine tetraacetic acid (EDTA), phenyl methyl sulfonyl flouride (PMSF), iodoacetic acid (IAA) and Bromophenacyl bromide (BPB). The enzyme activity for thermal stability and effect of metal ion and inhibitors were presented as relatives activity (\%) with aquadest was used as a control.

\subsection{MTGase Activity}

MTGase activity was measured base on the formation of hidroksamat from N-carbobenzoxyl-Lglutaminilglycine (CBZ) as described by $\mathrm{Ho}$ et al., 2000. The mixture of $100 \mu \mathrm{L}$ enzyme, a substrate (25 $\mu \mathrm{L} 0.1 \mathrm{M}$ Glutathion, $25 \mu \mathrm{L} 2.0 \mathrm{M}$ Hydroxylamine dan $75 \mu \mathrm{L} 0.1 \mathrm{M} \mathrm{CBZ}$ ) and $200 \mu \mathrm{L}$ of $0,1 \mathrm{M}$ citrate bufer $\mathrm{H}$ 6 was incubated at $50{ }^{\circ} \mathrm{C}$ for 1 hour. The reaction was stopped by adding $425 \mu \mathrm{L}$ of $5.0 \% \mathrm{FeCl}_{3}$ in $15.0 \%$ TCA. The absorbance was measured at $\lambda 525 \mathrm{~nm}$. Lglutamic acid $\lambda$-monohydroxamate was used as a standar. One unit of MTGase activity was defined as amount of enzyme to catalyze $1 \mu \mathrm{mol}$ of L-glutamic acid $\lambda$-monohydroxamate per minute at $50^{\circ} \mathrm{C}$.

\section{Result and Discussion}

\subsection{Starter Age and Enzyme Production}

The age of culture on solid medium was investigated to ensure the stage where the isolate in optimum condition before being inoculated to liquid starter. Streptomyces thioluteus TTA 02 SDS 14 produced the highest activity in liquid medium using 6-day solid culture (Figure 1). Prabhahar et al. (2014) reported that Actinomycetes was incubated on solid medium for 7 days before being inoculated to liquid starter medium. Stretomyces thioluteus TTA 02 SDS 14 showed the slow growth during the investigation which was performed for 9 days. It allegedly also produced pigment due to the color of colony which seem white at $1^{\text {st }}-2^{\text {nd }}$ days and gradually change to light red after 5 days. The Gram stain of 6 -day culture evince filaments as investigated under microscope (Figure 2).

Streptomyces is Gram positive bacteria nonmotile with filament (Madigan \& Martinko, 2005). The color of colony gradually changed from yellow - pink to yellow - dark red depend on growth medium which will generate different product (Arcamone et al., 2000; Huk \& Blumauerová, 1989). Characteristic of Streptomyces varied depend on the composition of the medium used for growing which will generate different color of mycelium aerial as well pigment its produced (Taddei et al., 2006). The condition was showed by Penicillium sp. which produced low concentration of red pigment while high concentration was produced in medium with peptone as a nitrogen source. (Gunasekaran \& Poorniammal, 2008).

The $6^{\text {th }}$ - day culture from the solid medium was used to determine the age of starter in the the liquid medium. The investigation showed that the $6^{\text {th }}$-day solid starter (optimum age of solid starter) produced MTGase with the the highest activity after incubating in liquid starter for 6 days (Figure 3 ). The incubation time for starter plays important role in enzyme production. After 6 days incubation, the medium showed pink color (Figure 2C). The color looked strong compared to the day before. The same result was showed by Mahmood (2013) that the optimum activity of MTGase production was reached after 6 days

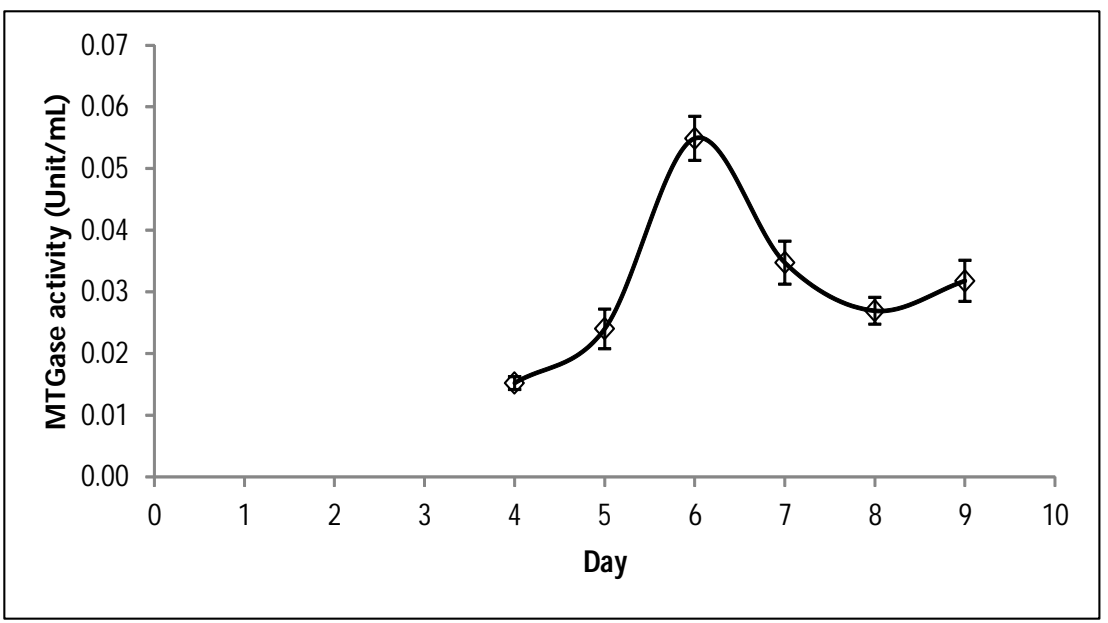

Figure 1. Activity of MTGase produced by Streptomyces thioluteus TTA 02 SDS 14 after 3 days fermentation using various of solid starter age. 


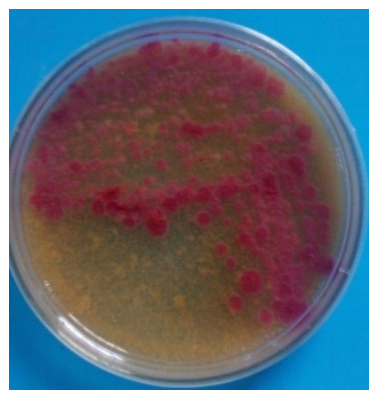

A

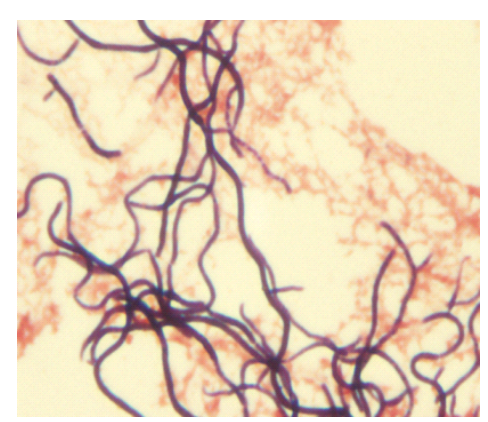

B

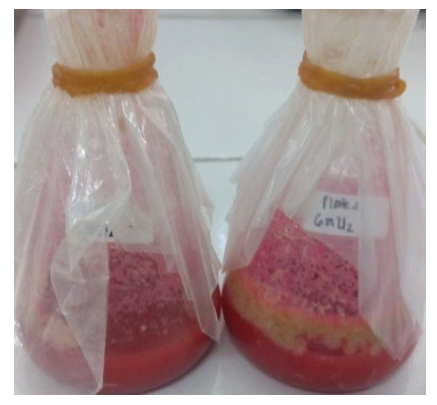

C

Figure 2. Streptomyces thioluteus TTA 02 SDS 14 grown in Bahrim media. Solid media (A) after 3 days incubation, under microscope 1000x (B), and in liquid medium after 5 days incubation (C).

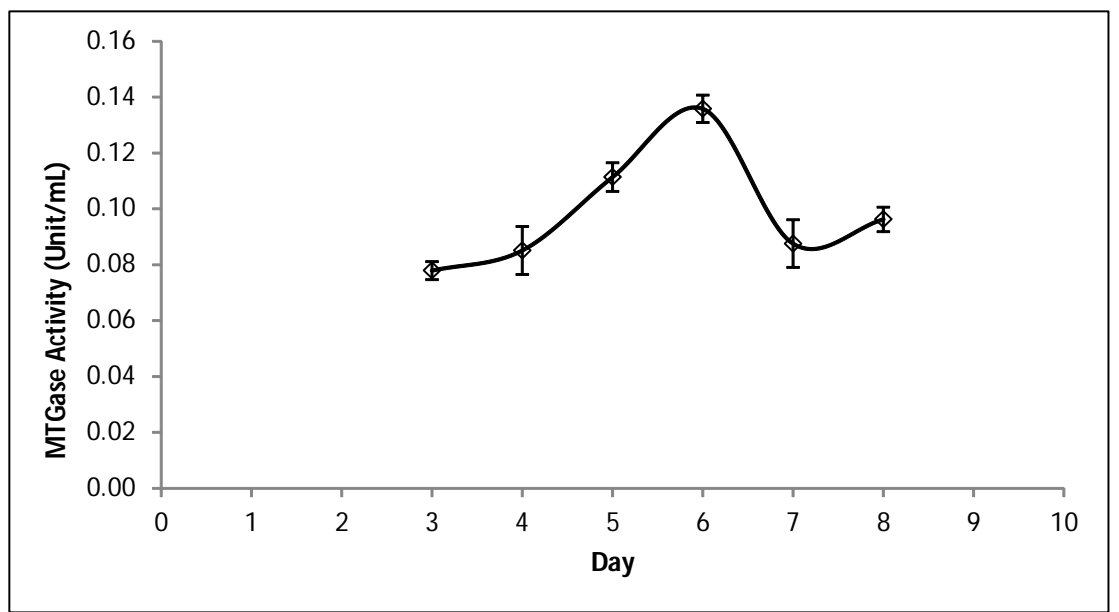

Figure 3. Activity of MTGase produced by Streptomyces thioluteus TTA 02 SDS 14 after 3 days fermentation using 6 day solid starter in various of liquid starter age.

incubation. The activity of MTGase produced by Streptomyces sp. TTA 02 SDS was tend to decrease after 6 days incubation. The decreasing of enzyme activity after 6 days incubation allegedly was caused by the lack of nutrient, the water content in medium, production of toxic compounds and autolysis of product (Sumantha et al., 2006).

\subsection{MTGase Production}

The optimum starter $\left(6^{\text {th }}\right.$-day solid starter was inoculated into liquid medium and incubated for 6 days), was used for enzyme production which was carried out in $5 \mathrm{~L}$ bioreactor with $2 \mathrm{~L}$ production volume. The $\mathrm{pH}$ of the medium was adjusted to 6 and temperature for incubation was set at $30{ }^{\circ} \mathrm{C}$ as previously reported by Fawzya et al. (2016). The result showed that $S$. thioluteus TTA 02 SDS 14 produced MTGase optimally with $150 \mathrm{rpm}$ agitation
(Figure 4). High activity MTGase has produced at the first day of fermentation and reached the highest activity at the second day. The production with 100 rpm agitation need a longer time to generate MTGase. The agitation level is the important parameter for enzyme production which correlated to the amount of oxygen needed by the isolates. Streptomyces hygroscopicus needed $500 \mathrm{rpm}$ agitation in fed-batch fermentor system to produced MTGase optimally after being incubated for 72 hours (Aidaroos et al., 2011) while Streptomyces mobaraensis needed 200 rpm agitation (Guerra-Rodriguez \& Vazquez, 2013)

\subsection{MTGase Characterization}

\subsubsection{Effect of $p H$ on MTGase activity}

The crude MTGase produced by $S$. thioluteus TTA02 SDS 14 was active the most at $\mathrm{pH}$ of 6 in citrate buffer (Figure 5 ) and temperature of $45-50^{\circ} \mathrm{C}$. 


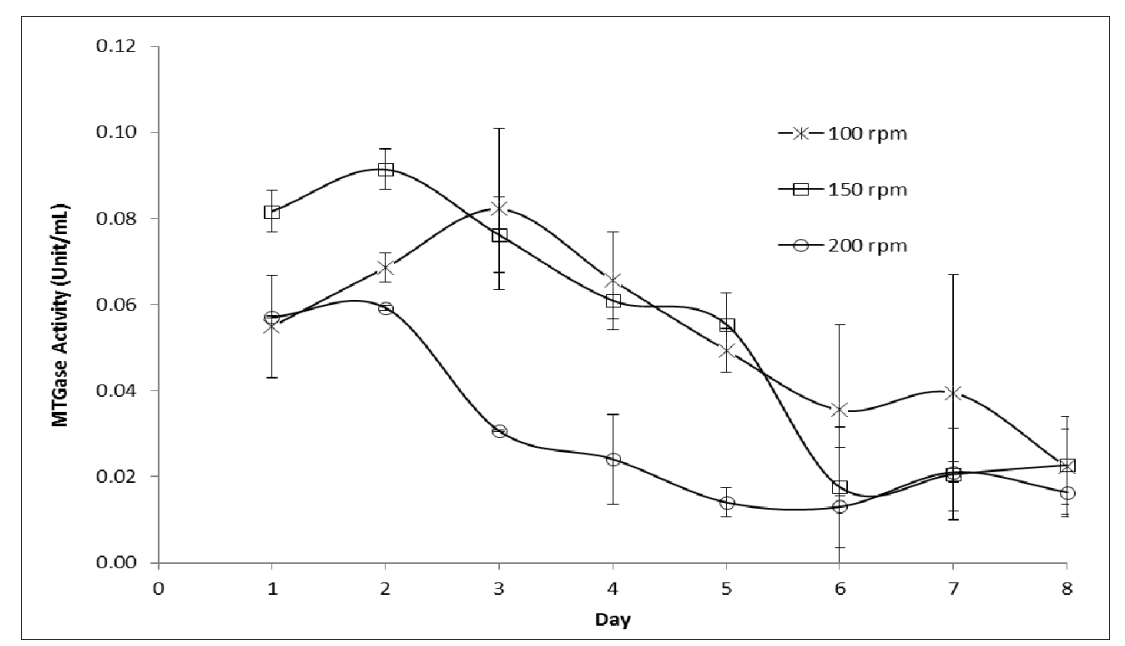

Figure 4. Activity of MTGase produced by Streptomyces thioluteus TTA 02 SDS 14 in 2 L work volume medium using $5 \mathrm{~L}$ bioreactor inoculated with optimum starter (6-day liquid starter inoculated with 6-day solid starter).

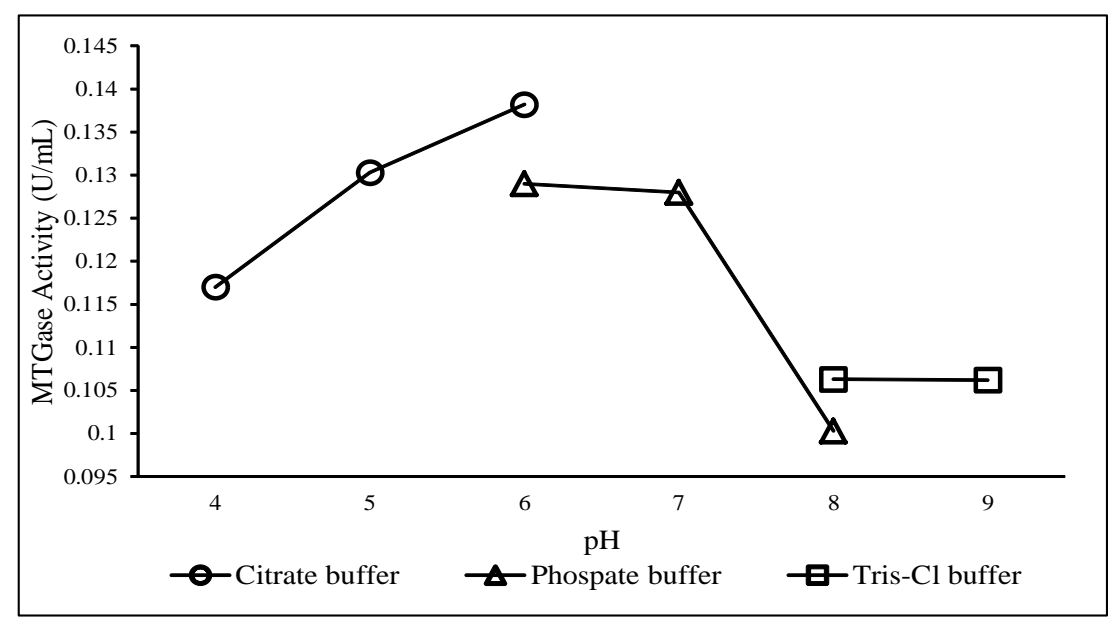

Figure 5. Activity of crude MTGase produced by Streptomyces thioluteus TTA 02 SDS 14 in various of pH buffer.

Macedo et al. (2011) revealed that MTGase produced by microorganisms exhibited optimum activity in a $\mathrm{pH}$ range of 6.0-6.5 exception for those produced by Bacillus subtilis which was active the most at the quiet different $\mathrm{pH}, 8.2$ (Suzuki et al., 2000) which similar to TGase produced by mammals and fish (Worratao \& Yongsawatdigul, 2005). High activity was detected in the range of test temperature $\left(25-75^{\circ} \mathrm{C}\right)$ but the crude MTGase produced by Streptomyces thioluteus TTA 02 SDS 14 showed the highest activity $50^{\circ} \mathrm{C}$.

\subsubsection{Effect of metal ions on crude MTGase activity}

The relative activity of MTGase was investigated in the presence of several metal ions which was added in final concentration of $10 \mathrm{mM}$. The results showed that addition of ions affected the activity of crude MTGase produced by Streptomyces sp. TTA 02 SDS 14 which some of them enhanced i.e $\left(\mathrm{K}^{+}, \mathrm{Na}^{+}, \mathrm{Mg}^{2+}\right.$ and $\left.\mathrm{Ca}^{2+}\right)$ and some slightly decrease $\left(\mathrm{Fe}^{3+}, \mathrm{Zn}^{2+}, \mathrm{Li}^{2+}\right.$ and $\mathrm{Cu}^{2+}$ ) the activity. This result was similar with MTGase produced by Streptoverticilium ladakanum ATCC 27441 (Ho et al., 2000) and Streptovercilium S8112 (Ando et al., 1989). Ho et al. (2000) reaveled that inhibition by ions preferably caused by the reaction betwen ions and $\mathrm{SH}$ group in catalytic reaction which affect the enzyme activity.

\subsubsection{Effect of inhibitors on MTGase activity}

The relative activity of transglutaminase was investigated in the presence of several inhibitors such as EDTA, PMSF, IAA and BPB which was added in 


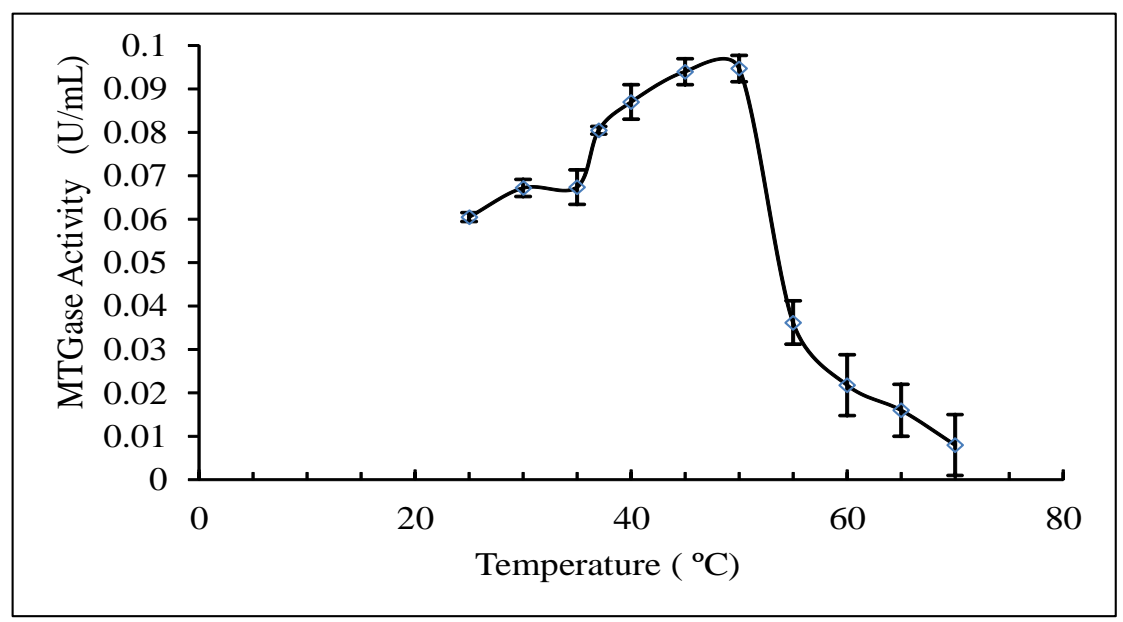

Figure 6. Activity of crude MTGase produced by Streptomyces thioluteus TTA02 SDS 14 at various of temperature.

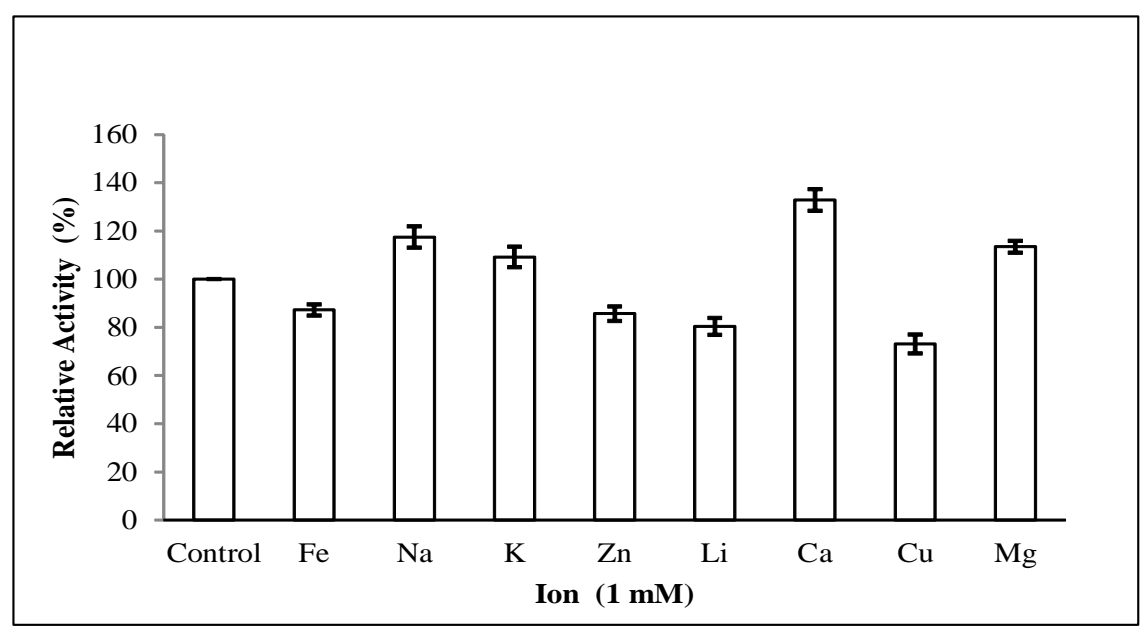

Figure 7. Activity of crude MTGase produced by Streptomyces thioluteus TTA02 SDS 14 in the present of metal ion as chloride solution with final concentration of $1 \mathrm{mM}$.

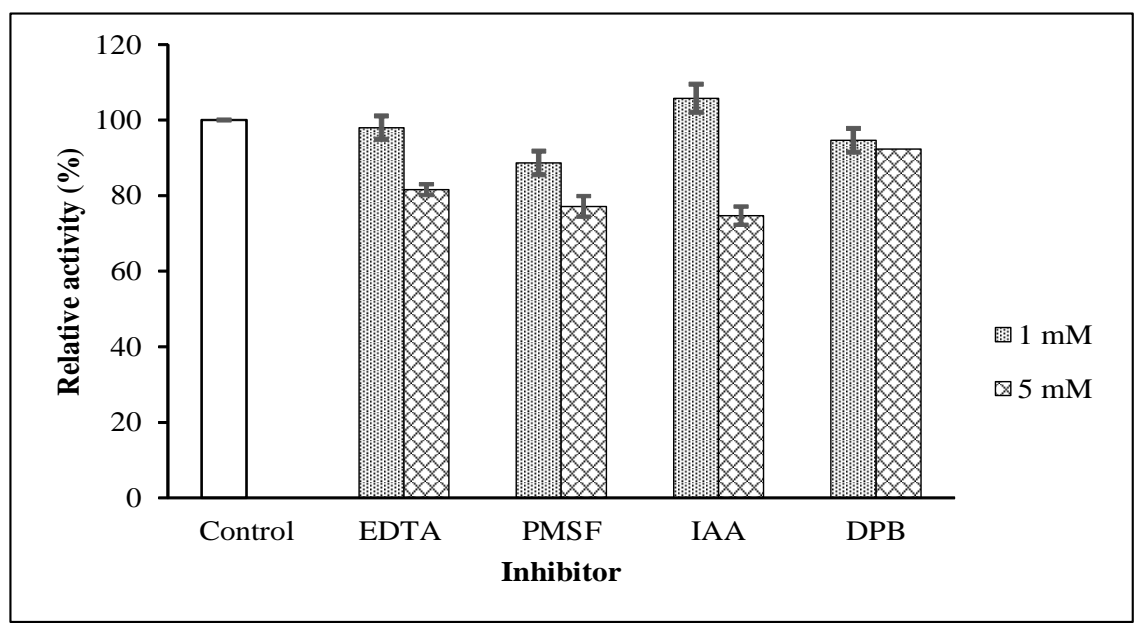

Figure 8. Activity of crude MTGase produced by Streptomyces thioluteus TTA 02 SDS 14 in the presence of inhibitors with final concentration of 1 and $5 \mathrm{mM}$. 
different concentrations according to the methodology. The activity of crude MTGase produced by $S$. thioluteus TTA 02 SDS14 is shown in Figure 8. The result showed that none of inhibitors affected enzyme activity. The addition of EDTA which nor affected enzyme activity confirmed that this enzyme is not a metalo enzyme. The previous results also showed that none of the tested ions enhance enzyme activity more than 50\% (Fawzya et al., 2016).

\section{Conclusion}

Starter age of local isolate, Streptomyces thioluteus SDS TTA 02 SDS 14 was found optimally producing MTGase after incubating for 6 days on solid media continued in liquid medium for 6 days. The optimization of enzyme production using optimum starter showed that Streptomyces thioluteus TTA02 SDS 14 produced the highest activity of MTGase after 2 days fermentation with $150 \mathrm{rpm}$ agitation. The crude enzyme produced by this isolate active optimally at $45-50{ }^{\circ} \mathrm{C} \mathrm{pH}$ of 6 and the enzyme has no effect on addition of both metal ions and inhibitors. The optimized starter age is expected can be continued by further experiments to obtain a proper condition for MTGase production using this local isolate.

\section{References}

Aidaroos, H.I., Du, G., \& Chen, J. (2011). Microbial fedbatch production of transglutaminase using ammonium sulphate and calcium chloride by Streptomyces hygroscopicus. Biotechnol Bioinf Bioeng., 1(2), 173-178.

Ando, H., Adachi, M., Umeda, K., Matsuura, A., Nonaka, M., Uchio, R., ... \& Motoki, M. (1989). Purification and characteristics of a novel transglutaminase derived from microorganisms. Agricultural and Biological Chemistry, 53(10), 2613-2617.

Arcamone, F., Cassinelli, G., Fantini, G., Grein, A., Orezzi, P., Pol, C., \& Spalla, C. (2000). Adriamycin, 14hydroxydaunomycin, a new antitumor antibiotic from S. peucetius var. caesius. Biotechnol Bioeng., 67(6), 704-713.

Bahrim, G., lancu, C., Butu, N. \& Negoita, T.G. (2010). Production of a novel microbial transglutaminase using Streptomyces $s p$. polar strains. Roman Biotechnol Lett. 15 (2) : 5197 - 5203

Falcone, P., Serafini-Fracassini, D., \& Del Duca, S. (1993). Comparative studies of transglutaminase activity and substrates in different organs of Helianthus tuberosus. Journal of plant physiology, 142(3), 265-273.

Fawzya, Y. N., Zilda, D. S., Chaniago, S., Prestisia, H. N., Lisdiyanti, P., \& Khasanah, N. (2016). Screening of Indonesian Streptomyces sp. Capable of Secreting
Transglutaminase (Mtgase) and Optimization of Mtgase Production Using Different Growth Media. Squalen Bulletin of Marine and Fisheries Postharvest and Biotechnology, 11(1), 13-21.

Gaspar, A. L. C., \& de Góes-Favoni, S. P. (2015). Action of microbial transglutaminase (MTGase) in the modification of food proteins: A review. Food chemistry, 171, 315-322.

Griffin, M., Casadio, R., \& Bergamini, C. M. (2002). Transglutaminases: nature's biological glues. Biochemical Journal, 368(2), 377-396.

Guerra-Rodríguez, E., \& Vázquez, M. (2014). Evaluation of a novel low-cost culture medium containing exclusively milk, potato and glycerol for microbial transglutaminase production by Streptomyces mobaraensis. Chemical Engineering Research and Design, 92(4), 784-791.

Gunasekaran, S., \& Poorniammal, R. (2008). Optimization of fermentation conditions for red pigment production from Penicillium $\mathrm{sp}$. undersubmerged cultivation. Afric. J. of Biotechnol., 7(12), 1894-1898.

Ho, M.L, Leu., S.Z., Hsieh, J.F. \& Jiang, S.T. (2000). Technical approach to simplify the purification method and characterization of microbial transglutaminase produced from Streptoverticillium ladakanum. J Food Sci. 65 (1) : $76-80$.

Huk, J., \& Blumauerová, M. (1989). Streptomycetes producing daunomycin and related compounds: do we know enough about them after 25 years? Folia Microbiol., 34, 324-349.

Macedo, J.A., Sette, L.D. \& Sato, H.H. 2010. Purification and characterization of a new transglutaminase from Streptomyces sp. isolated in Brazilian soil. J Food Biochem. $35: 1361$ - 1372.

Madigan, M.T. \& Martinko, J.M. (2005). Brock Biology of Microorganisms. Ed ke-11. Prentice Hall. London.

Mahmood, W. A. (2013). Production of transglutaminase by a local Streptomyces isolate using wheat bran. Jordan J. of Agricul Sci., 9(1), 33-42.

Motoki, M., \& Seguro, K. (1998). Transglutaminase and its use for food processing: Review. J. Food Sci Technol., 9(5), 204-210.

Pangsorn, S., Laong-manee P., Siriraksophon, S. (2007). Status of surimi industry in the Southeast Asia. Training Department, Southeast Asian Fisheries Development Center, Thailand.

Prabhahar, C., Saleshrani, K., \& Enbarasan, R. (2014). Isolation and characterization of marine actinomycetes from Muthuppettai mangroves, Tamilnadu, India. International J. of Recent Sci. Research., 5(4), 906-910

Sumantha, A., Deepa, P., Sandhya, C., Szakacs, G., Soccol, C., \& Pandey, A. (2006). Rice bran as a substrate for proteolytic enzyme production. Braz. Arch. Biol. Technol., 49, 843-851.

Suzuki, S. I., Izawa, Y., Kobayashi, K., Yamanaka, S., Kubota, K., \& Yokozeki, K. (2000). Purification and 
characterization of novel transglutaminase from Bacillus subtilis spores. Bioscience, biotechnology, and biochemistry, 64(11), 2344-2351.

Taddei, A., Rodriguez, M. J., Marquez-Vilchez, E., \& Castelli, C. (2006). Isolation and identification of Streptomyces spp. From Venezuelan soils: morphological and biochemical studies. I. Microbiol Research.,161, 222-231.
Worratao, A., \& Yongsawatdigul, J. (2005). Purification and characterization of transglutaminase from Tropical tilapia (Oreochromis niloticus). Food Chemistry, 93(4), 651-658.

Yasueda, H., Kumazawa, Y., \& Motoki, M. (1994). Purification and characterization of a tissue-type transglutaminase from red sea bream (Pagrus major). Bioscience, biotechnology, and biochemistry, 58(11), 2041-2045. 